Artigo Original

\title{
Radioactive Iodine for the Treatment of Graves Disease in Paediatric Age: The Experience of a Tertiary Centre and Literature Review
}

\author{
Nuno Vicente ${ }^{\mathrm{a},{ }^{*},}$ Luís Cardoso ${ }^{\mathrm{a}}$, Joana Serra Caetano ${ }^{\mathrm{b}}$, Rita Cardoso ${ }^{\mathrm{b}}$, Isabel Dinis ${ }^{\mathrm{b}}$, \\ Gracinda Costa ${ }^{\mathrm{c}}$, Luísa Barros ${ }^{\mathrm{a}}$, Francisco Carrilho ${ }^{\mathrm{a}}$, Alice Mirante ${ }^{\mathrm{b}}$ \\ ${ }^{a}$ Serviço de Endocrinologia, Diabetes e Metabolismo, Centro Hospitalar e Universitário de Coimbra, Coimbra, Portugal \\ ${ }^{b}$ Unidade de Endocrinologia Pediátrica, Centro Hospitalar e Universitário de Coimbra, Coimbra, Portugal
}

' Serviço de Medicina Nuclear, Centro Hospitalar e Universitário de Coimbra, Coimbra, Portugal

\section{INFORMAÇÃO SOBRE O ARTIGO}

Historial do artigo:

Received/ Recebido: 2017-12-29

Online: 2020-01-22

(C) Autor (es) (ou seu (s) empregador (es)) 2019.

Reutilização permitida de acordo com

CC BY-NC. Nenhuma reutilização comercial.

(C) Author(s) (or their employer(s)) 2019.

Re-use permitted under CC BY-NC.

No commercial re-use.

\section{Keywords:}

Child;

Graves Disease/radiotherapy;

Iodine Radioisotopes/therapeutic use
Accepted/Aceite: 2019-10-06

\begin{abstract}
A B S T R A C T
Introduction: Graves' disease affects individuals in paediatric age of all ages and recent epidemiological data point to an increase in its incidence. These data highlight the importance of knowing and differentiating the diverse therapeutic options available. Radioactive iodine (RAI) - in the present context, we refer specifically to iodine-131 (I131) has demonstrated its efficacy in the treatment of hyperthyroidism for more than 70 years. It is commonly used as a second line drug, after failure of anti-thyroid drugs. In this study, the authors describe the experience with RAI in the treatment of children with Graves' disease in a single Portuguese Paediatric centre.

Methods: Retrospective analysis of all cases of children with Graves' disease who were treated with RAI. The goal of treatment was the achievement of hypothyroidism after which, therapy with levothyroxine would be started. The activity of RAI was estimated individually according to RAI glandular uptake at 24 hours and functional thyroid parenchymal mass.

Results: Seven patients with Graves' disease, who relapsed after adequate treatment with anti-thyroid drugs, were treated with RAI. They were all female, with ages ranging from 12.7 to 16.3 years at first treatment (median; inter-quartile range; 13.9; 13.5-15.1 years). Patients received an activity between 203.5 and $555 \mathrm{MBq}(5,5-15 \mathrm{mCi})$, with a median of $370 \mathrm{MBq}(10 \mathrm{mCi})$. Hypothyroidism was achieved after a median period of 6 months. Two patients needed an additional RAI treatment, becoming hypothyroid 1 month later. This results correspond to an efficacy of $71.4 \%$ and $100 \%$, after one or two treatments, respectively ( $85.7 \%$ globally). There were no side effects.

Conclusion: RAI was a safe and effective option for the definitive treatment of hyperthyroidism in paediatric Graves' disease.
\end{abstract}

\section{Terapêutica Ablativa com Iodo Radioativo em Idade Pediátrica: A Experiência de um Hospital Central e Revisão da Literatura}

Criança;

Doença de Graves/radioterapia;

Radioisótopos do Iodo/uso terapêutico

\begin{abstract}
Introdução: A doença de Graves atinge a população pediátrica em quase todas as faixas etárias e os dados epidemiológicos mais recentes apontam para um aumento da sua incidência. Este dado reforça a necessidade de conhecer, e posicionar entre si, as diversas as opções terapêuticas disponíveis. O iodo radioativo (IRA) - referimos neste contexto especificamente o iodo-131 (I131) - tem demonstrado, desde há mais de 70 anos, grande eficácia no tratamento do hipertiroidismo. É habitualmente usado como fármaco de segunda linha, após falha dos anti-tiroideus de síntese. Neste trabalho, os autores descrevem a experiência de um Hospital Pediátrico Português com o IRA no tratamento de crianças com doença de Graves.
\end{abstract}

Métodos: Análise retrospetiva de todos os casos de doença de Graves submetidas a tratamento com

\footnotetext{
"Autor Correspondente / Corresponding Author. E-Mail: nunovic@gmail.com (Nuno Vicente) Centro Hospitalar de Leiria, Rua das Olhalvas, 2400 Leiria, Portugal
} 
IRA. O objetivo do tratamento foi o hipotiroidismo, a partir do qual se iniciaria terapêutica de substituição com levotiroxina. A atividade de I131 foi estimada individualmente tendo em conta a captação glandular de IRA às 24 horas e a massa de parênquima tiroideu funcionante.

Resultados: Sete crianças com doença de Graves que recidivaram após tratamento adequado com anti-tiroideus de síntese, receberam IRA. Eram todas do género feminino, com idades compreendidas entre os 12,7 e os 16,3 anos aquando do primeiro tratamento (mediana; intervalo interquartil: 13,$9 ; 13,5-15,1$ anos). Receberam uma atividade que variou entre os 203,5 e $555 \mathrm{MBq}(5,5-15 \mathrm{mCi})$, com uma mediana de $370 \mathrm{MBq}(10 \mathrm{mCi})$. O hipotiroidismo foi atingido, em média, 6 meses após o tratamento. Duas crianças necessitaram de um tratamento adicional com IRA, tendo atingido o hipertiroidismo em cerca de 1 mês. Com estes resultados obteve-se uma eficácia de 71,4\% e 100\%, após um ou dois tratamentos, respetivamente (eficácia global 85,7\%)

Conclusão: IRA foi uma opção segura e eficaz para o tratamento definitivo do hipotiroidismo na doença de Graves em idade pediátrica.

\section{Introduction}

Graves' disease is an autoimmune disorder, characterized by anomalous production of autologous antibodies against the TSH receptor (TSH receptor antibodies or TRAbs). The main consequence of this, is the overstimulation of the follicular thyroid cells, leading to an autonomous and uncontrolled synthesis and subsequent release of thyroid hormones into the bloodstream. ${ }^{1}$ Graves' disease has an annual incidence rate of 21.4 new cases per 100000 inhabitants in adults ${ }^{2}$ and is the most frequent cause of thyrotoxicosis. In children, Graves' disease is rarer and accounts for only $1 \%-5 \%$ of total cases, ${ }^{3}$ with annual incidence rates across European countries varying between 0.4 and 1.5 per 100000 inhabitants. ${ }^{4}$ It may be diagnosed at any age, but peaks in adolescence, with estimated incidence rates of $0.1 / 100000$ person-years in early childhood to $3.0 / 100000$ in adolescence. ${ }^{5}$ However, a Chinese study reported a trend in increasing incidence of Graves' disease in paediatric age ${ }^{6}$ which renders the management of this disorder increasingly important.

The treatment options in children with Graves' disease are similar to those for adults. Anti-thyroid drugs are usually the first option and paediatricians can choose between carbimazole (when available) and methimazole. Since 2010, propylthiouracil is no longer recommended by the U.S. Food and Drug Administration because of the unacceptable risk of liver damage. ${ }^{7}$ Anti-thyroid drugs can be titrated alone or be administered together with levothyroxine ("block and replace" regimen). While anti-thyroid drugs as first line option for treatment is consensual, remission rates generally do not exceed $20 \%$ - 30\% after $1-2$ years of therapy. ${ }^{8}$ In those cases, a definitive alternative for the resolution of hyperthyroidism is needed. The remaining options are surgery (near total or total thyroidectomy) or radioactive iodine (RAI), with the former being preferred for children younger than 5 years, for large thyroid glands (more than $80 \mathrm{~g}$ ) and for cases associated with active ophtalmopathy. ${ }^{8}$ Despite being a valuable and effective option, some concerns still exist regarding the risk of future malignancies and that may be the cause why RAI has been avoided in paediatric Graves' disease.

The aim of this study was to evaluate the outcomes of RAI for the treatment of Graves' disease in a single Portuguese paediatric centre.

\section{Methods}

Retrospective analysis of all Graves' disease cases diagnosed in patients younger than 18 years, referred for RAI treatment between 2006 and 2015. All patients failed to achieve remission after the first line treatment with methimazole with a "block and replace" regimen. Indications for RAI were persistent hyperthyroidism, a thyroid gland weighing less than $80 \mathrm{~g}$ and absence of active eye disease. The treatment goal was the hypothyroid state, which was then properly corrected with levothyroxine therapy. Methimazole was routinely stopped 1 week prior to RAI and therapeutic activity was estimated individually, using the following formula: Therapeutic activity $(\mathrm{MBq})=($ specific activity $x m x$ 100) $/ u$ (where $m$ is functional parenchymal mass in grams and $u$ is the percentage of RAI glandular uptake at 24 hours). Thyroid size was estimated by ultrasound. All patients and caregivers followed the radiation safety recommendations presented prior to the treatment. Possible adverse effects related to RAI were actively searched in the follow-up visits. Patients were observed every four weeks after treatment and thyroid function tests (TSH, free T4, free T3 and TSH receptor antibodies) were requested on each visit. Indication to start levothyroxine after RAI was a measurement of TSH $>10 \mathrm{mUI} / \mathrm{dL}$ in the follow-up visits.

All the statistical analyses were performed with the software Microsoft Excel ${ }^{\circledR} 2016$.

\section{Results}

Seven children, all females, with a median age on the first RAI treatment of 13.9 years, were submitted to RAI therapy in our Hospital. The first treatment was performed in 2010 and the me-

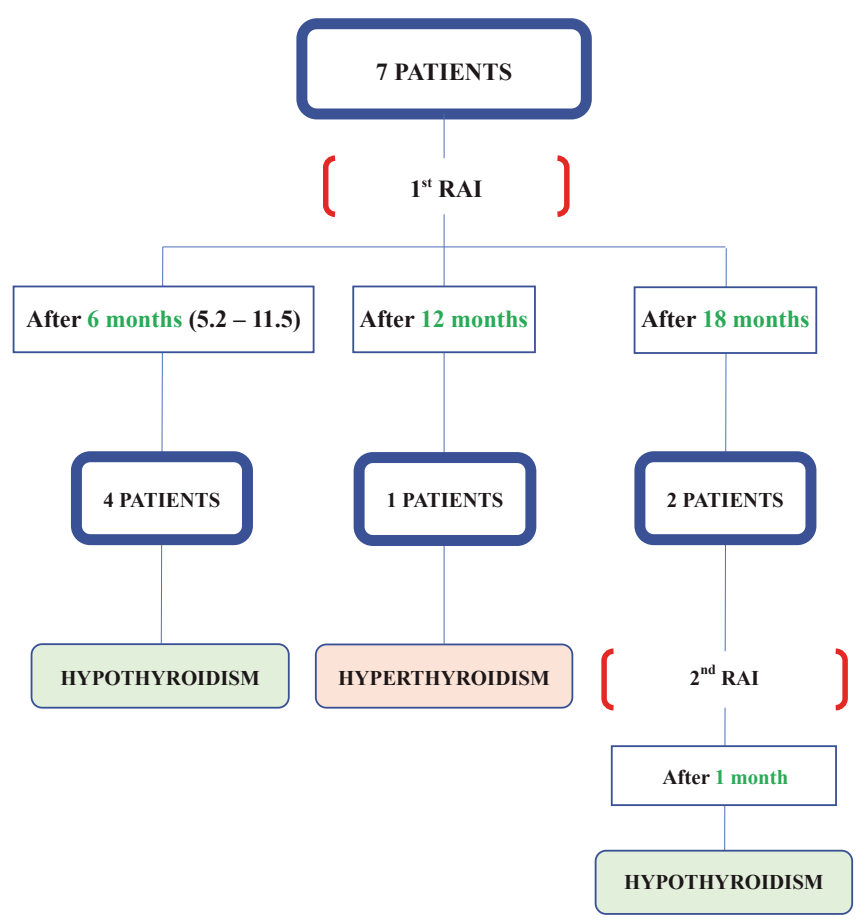

Figure 1. Patients' follow-up after RAI 
dian time on methimazole therapy prior to RAI was 41 months. The general characteristics of the patients are shown in Table 1 and a flowchart summarizing the follow-up of the patients is presented in Fig. 1.

Table 1. Summary of characteristics.

\begin{tabular}{lcc}
\hline & Median & IQR \\
\hline Age of onset of GD (years) & 10.1 & $9.9-10.8$ \\
\hline Free T4 before methimazole (ng/dL) & 3.30 & $1.8-5.4$ \\
\hline $\begin{array}{l}\text { TSH receptor antibodies before methima- } \\
\text { zole (IU/L) }\end{array}$ & 11.2 & $3.8-16.3$ \\
\hline $\begin{array}{l}\text { Duration of methimazole treatment until } \\
\text { RAI (months) }\end{array}$ & 41 & $33-52$ \\
\hline TSH before RAI (mIU/mL) & 0.297 & $0.008-3.700$ \\
\hline Free T4 before RAI (ng/dL) & 1.0 & $0.9-1.8$ \\
\hline TSH receptor antibodies before RAI (IU/L) & 3.60 & $0.46-12.15$ \\
\hline Age at $\mathbf{1}^{\text {st }} \mathbf{R A I}$ (years) & 13.9 & $13.5-15.1$ \\
\hline Activity of $\mathbf{1}^{\text {st }} \mathbf{I}^{\mathbf{1 3 1}}$ (mCi) & 10 & $9-13$ \\
\hline IQR - interquartile range; & &
\end{tabular}

The higher activities seemed to be related to less time to hypothyroidism (Fig. 2). Two patients needed a second RAI treatment and hypothyroidism was achieved 1 month later in both. When comparing the activities of the two groups (single and 2-session), we notice that the activities were lower in the former, $407 \mathrm{MBq}$ vs

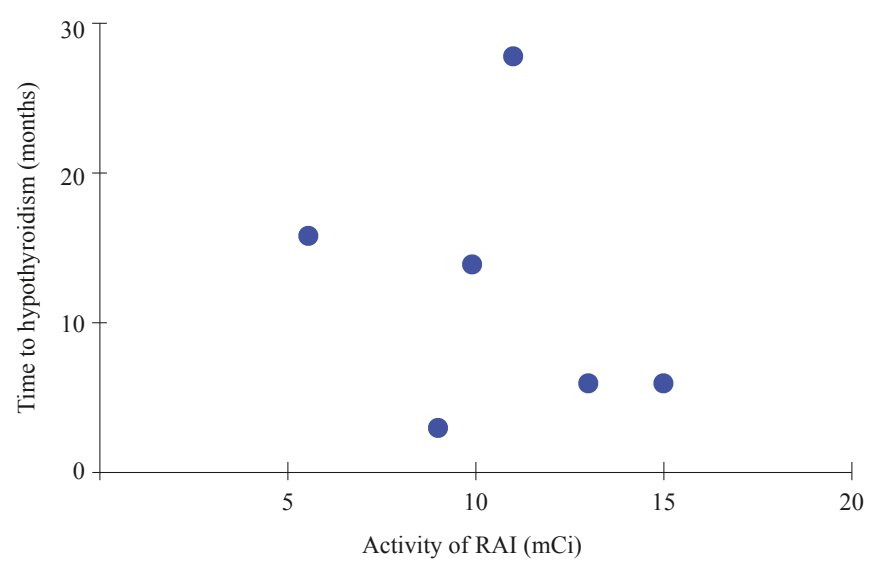

Figure 2. Effect of RAI activity on hypothyroidism

$629 \mathrm{MBq}$ (11 vs $17 \mathrm{mCi}$ ) - Table 2. One patient remained in hyperthyroidism, with low TSH levels 12 months after RAI, despite being out of methimazole.

Apart from hypothyroidism, which was an intended outcome, no side effects were observed in any of the patients.

Table 2. Comparison of total RAI activity between both groups.

\begin{tabular}{lcc}
\hline & \multicolumn{2}{c}{ Total activity of RAI (mCi) } \\
\cline { 2 - 3 } & Median & IQR \\
\hline Single session RAI & 11 & $10-13$ \\
\hline Two-sessions RAI & 17 & $15.1-19$ \\
\hline IQR - interquartile range. & &
\end{tabular}

\section{Discussion}

The fact that patients in our sample were only female is a consequence of the known predominance of the female gender in Graves' disease ${ }^{3}$ and to a reduced number of individuals. Despite the decreasing use of the "block and replace" strategy, ${ }^{8}$ the choice of this modality of treatment (which uses higher doses of anti-thyroid drugs) does not carry disadvantages in terms of efficacy. ${ }^{9,10}$ In fact, the option for RAI was perfectly justifiable by the long period in hyperthyroidism (41 months). Recent guidelines recommend RAI or surgery after, at least, 1 or 2 years of treatment with methimazole, if remission is not achieved. These new orientations changed the previous perspective that anti-thyroid drugs could be administered for up to 8-10 years until a definitive alternative could be applied. ${ }^{11}$ Remarkably, prior to RAI patients had low/low normal TSH and high TSH receptor antibody levels under methimazole (Table 1), which is indicative of absence of control of the hyperthyroidism and Graves' autoimmune activity, respectively, further supporting the option for RAI.

RAI has been used in children with safety for many years. A cohort of 107 patients under 20 years of age, 98 of whom followed for a period of 36 years, showed no evidence of neoplasia. ${ }^{12}$ In fact, the greatest concern comes from the fact that after the Chernobyl incident, there was a great number of thyroid malignancies (the majority of the cases were exposed before 1 year of age with increased risk between 0-4 years of age at time of exposure), ${ }^{13}$ leading to some discomfort about this option. However, the risk of thyroid cancer is related to exposure to low/medium levels of external radiation, rather than the higher activities needed for thyroid ablation. ${ }^{14} \mathrm{Cur}$ rently, there is a consensus to avoid RAI before the age of 5, due to a higher total body exposure per mCi of RAI exposure when age decreases and also to a theoretical lifetime risk of malignancy ${ }^{3} 4 \%$, when a hypothetical activity of $15 \mathrm{mCi}$ is administered to patients with Graves' disease under 5 years of age. ${ }^{8}$ The patients of the current report were older (median age 13.9 years) when administered the first RAI, in accordance to the guidelines.

As in our report, the main goal of RAI is to administer enough activity to achieve hypothyroidism, because otherwise, the partially irradiated remaining thyroid tissue would be associated to a higher risk of thyroid cancer. ${ }^{15}$ Additionally, lower activities also lead to poor remission rates. Some groups administer a fixed dose of $\mathrm{I}_{131}$ of approximately $555 \mathrm{MBq}(15 \mathrm{mCi}),{ }^{16,17}$ but others calculate it individually according to RAI uptake and thyroid mass, as it was done in our centre. Both options seem legit in terms of efficacy, but the individualized approach enables less activities to be administered, especially if the uptake is high and the thyroid is small. ${ }^{8}$ As we are treating patients of paediatric age, long term safety is a priority and the main outcome of hypothyroidism should be reached with the minimum efficient RAI activity.

It is worth noticing the quickness of establishment of hypothyroidism after the first (6 months) and the second (1 month) RAI sessions - Fig. 1. There was only one patient who did not become hypothyroid after the first RAI, with supressed TSH, despite normal free T4 and TSH receptor antibodies levels out of medication; this patient will most certainly need a second RAI (not yet programmed). Although it is not presented as a clear line, there seems to be a trend with higher activities leading to less time to hypothyroidism (Fig. 2). This is compliant with the literature, which states that after an adequate RAI dose, hypothyroidism will develop in 6 to 8 weeks. ${ }^{14}$

If after a period of 6 months, hyperthyroidism is maintained, then a second RAI treatment is indicated. The patients from our 
sample that remained in hyperthyroidism after the first RAI session were offered a second RAI session 18 months after the first, which may have been a little late. In our analysis, the children from the group that received two RAI sessions, were offered more activity than the individuals from the single-RAI group (Table 2), which was not surprising. Indeed, hypothyroidism developed one month later in the two patients of the two RAI sessions group. However, one cannot assume if this was due to the higher activity or due to a second radioactive injury.

The possible side effects are related to RAI mechanism of action. After ingestion, RAI (as well as organic iodine) enters the circulation and is preferentially located in the thyroid, by a mechanism of active transport mediated by the $\mathrm{Na}+$ /I- symporter (NIS). The entrapment of iodine that usually occurs in order to synthesize thyroid hormones makes it possible for beta radiation emitted from $I_{131}$ to destroy healthy thyrocytes in a path length of 1-2 mm. ${ }^{14}$ Additionally, beta radiation also interacts with $\mathrm{H} 2 \mathrm{O}$ and $\mathrm{O} 2$ molecules, thus creating free radicals ( $\mathrm{H} 2 \mathrm{O} 2$ and $\mathrm{O} 2-$, respectively) whose accumulation will contribute to the intended destruction of the gland. However, NIS is not only located in the thyrocytes cell membrane, but also in the salivary glands, stomach, lactating breast, small intestine, kidney and placenta. ${ }^{18}$ Therefore, possible side effects reflect the location of NIS. They include mild pain secondary to radiation thyroiditis, which may develop 1-3 days after RAI and responds to non-steroidal anti-inflammatory drugs. Rarely, severe neck swelling and tracheal compression may occur, but are often associated either to large thyroid glands (in which RAI is not straightforwardly indicated) or activities much higher than needed for ablation. Nausea is a common transient problem, but is more frequent in adults. Other possible adverse effect is xerostomia related to radiation sialadenitis. However, it has been documented to occur mainly in patients with thyroid carcinoma, in whom higher activities of RAI are used for remnant ablation. ${ }^{19,20}$ Remarkably, the patients from our series had no adverse effects, which is assuring in terms of safety.

At the present moment, RAI has an efficacy of $85.7 \%$ (six permanently treated patients out of seven) in our sample. Such good results may reflect additional advantages. Besides the clinical benefits of the complete resolution of hyperthyroidism, patients will have less visits to the hospital, with subsequent reduction of health associated costs as well as less days off work for caregivers. Additionally, and despite the great majority of agranulocytosis cases occurring in the first 3 months of therapy, the extension of the anti-thyroid drug regimen for longer periods keeps the risk of anti-thyroid drug associated adverse events alive (some patients develop agranulocytosis 2 years after initiation of antithyroid drugs, especially if there is a discontinuation of the treatment $)^{21}$ which obviously will not happen after definitive hypothyroidism is reached. Other factor to bear in mind is the possibility of using RAI while there are no contraindications. This is valid for female adolescents, for whom a delay in RAI treatment until adulthood, when the possibility of motherhood is socially more acceptable, would contraindicate the definitive treatment and postpone even further the complete resolution. In these patients, the adjustment of the levothyroxine dose during a pregnancy is far easier to handle than the control of the hyperthyroidism. Furthermore, activities up to $9250 \mathrm{MBq}(250 \mathrm{mCi})$ as used for thyroid cancer were not associated to long-term risk of infertility in female children and adolescents. ${ }^{22}$ In male patients, the hyperthyroidism is associated to both reduced sperm volume and reduced sperm density, motility and impaired morphology $y^{23}$ and these deleterious effects of hyperthyroidism seem to be more harmful than the small ac- tivities of RAI commonly used for treatment. RAI improves both sperm quality and testosterone levels through restoration of a normal thyroid function. ${ }^{24}$

\section{Conclusion}

This is the largest group of paediatric patients with Graves' disease treated with RAI published in Portugal. The growing experience and satisfaction with the results and safety will most certainly increase the number of patients treated in the future. RAI is a good weapon for the treatment of Graves' disease that paediatricians and endocrinologists who follow these children must be aware of.

\section{Responsabilidades Éticas}

Conflitos de Interesse: Os autores declaram a inexistência de conflitos de interesse na realização do presente trabalho.

Fontes de Financiamento: Não existiram fontes externas de financiamento para a realização deste artigo.

Confidencialidade dos Dados: Os autores declaram ter seguido os protocolos da sua instituição acerca da publicação dos dados de doentes.

Proteção de Pessoas e Animais: Os autores declaram que os procedimentos seguidos estavam de acordo com os regulamentos estabelecidos pelos responsáveis da Comissão de Investigação Clínica e Ética e de acordo com a Declaração de Helsínquia da Associação Médica Mundial.

Proveniência e Revisão por Pares: Não comissionado; revisão externa por pares.

\section{Ethical Disclosures}

Conflicts of Interest: The authors have no conflicts of interest to declare.

Financing Support: This work has not received any contribution, grant or scholarship

Confidentiality of Data: The authors declare that they have followed the protocols of their work center on the publication of data from patients.

Protection of Human and Animal Subjects: The authors declare that the procedures followed were in accordance with the regulations of the relevant clinical research ethics committee and with those of the Code of Ethics of the World Medical Association (Declaration of Helsinki).

Provenance and Peer Review: Not commissioned; externally peer reviewed.

\section{References / Referências}

1. McIver B, Morris JC. The pathogenesis of Graves' disease. Endocrinol Metab Clin North Am. 1998;27:73-89.

2. Nystrom HF, Jansson S, Berg G. Incidence rate and clinical features of hyperthyroidism in a long-term iodine sufficient area of Sweden (Gothenburg) 2003-2005. Clin Endocrinol. 2013;78:768-76. doi: 10.1111/ cen. 12060 .

3. Leger J, Kaguelidou F, Alberti C, Carel JC. Graves' disease in children. Best Pract Res Clin Endocrinol Metab. 2014;28:233-43. doi: 10.1016/j. beem.2013.08.008.

4. Williamson S, Greene SA. Incidence of thyrotoxicosis in childhood: a national population based study in the UK and Ireland. Clin Endocrinol. 2010;72:358-63. doi: 10.1111/j.1365-2265.2009.03717.x.

5. Lavard L, Ranlov I, Perrild H, Andersen O, Jacobsen BB. Incidence of juvenile thyrotoxicosis in Denmark, 1982-1988. A nationwide study. Eur J Endocrinol. 1994;130:565-8. 
6. Wong GW, Cheng PS. Increasing incidence of childhood Graves' disease in Hong Kong: a follow-up study. Clin Endocrinol. 2001;54:547-50.

7. Rivkees SA. 63 years and 715 days to the "boxed warning": unmasking of the propylthiouracil problem. Int J Pediatr Endocrinol. 2010;2010. pii: 658267. doi: 10.1155/2010/658267.

8. Ross DS, Burch HB, Cooper DS, Greenlee MC, Laurberg P, Maia AL, et al. 2016 American Thyroid Association Guidelines for Diagnosis and Management of Hyperthyroidism and other causes of Thyrotoxicosis. Thyroid. 2016;26:1343-1421

9. Abraham P, Avenell A, McGeoch SC, Clark LF, Bevan JS. Antithyroid drug regimen for treating Graves' hyperthyroidism. Cochrane Database Syst Rev. 2010:CD003420. doi: 10.1002/14651858.CD003420.pub4.

10. Weetman AP. Graves' hyperthyroidism: how long should antithyroid drug therapy be continued to achieve remission? Nat Clin Pract Endocrinol Metab. 2006;2:2-3.

11. Leger J, Gelwane G, Kaguelidou F, Benmerad M, Alberti C, French Childhood Graves' Disease Study G. Positive impact of long-term antithyroid drug treatment on the outcome of children with Graves' disease: national long-term cohort study. J Clin Endocrinol Metab. 2012:97:110-9. doi: 10.1210/jc.2011-1944.

12. Read CH, Jr., Tansey MJ, Menda Y. A 36-year retrospective analysis of the efficacy and safety of radioactive iodine in treating young Graves' patients. J Clin Endocrinol Metab. 2004;89:4229-33.

13. Nikiforov Y, Gnepp DR, Fagin JA. Thyroid lesions in children and adolescents after the Chernobyl disaster: implications for the study of radiation tumorigenesis. J Clin Endocrinol Metab. 1996;81:9-14.

14. Rivkees SA, Sklar C, Freemark M. Clinical review 99: The management of Graves' disease in children, with special emphasis on radioiodine treatment. J Clin Endocrinol Metab. 1998;83:3767-76.

15. Rivkees SA. Controversies in the management of Graves' disease in children. J Endocrinol Invest. 2016;39:1247-57.
16. Nebesio TD, Siddiqui AR, Pescovitz OH, Eugster EA. Time course to hypothyroidism after fixed-dose radioablation therapy of Graves' disease in children. J Pediatr. 2002;141:99-103.

17. Cury AN, Meira VT, Monte O, Marone M, Scalissi NM, Kochi C, et al Clinical experience with radioactive iodine in the treatment of childhood and adolescent Graves' disease. Endocr Connect. 2013;2:32-7. doi: 10.1530/EC-12-0049.

18. Portulano C, Paroder-Belenitsky M, Carrasco N. The Na+/I- symporter (NIS): mechanism and medical impact. Endocr Rev. 2014;35:106-49. doi: 10.1210/er.2012-1036.

19. Grewal RK, Larson SM, Pentlow CE, Pentlow KS, Gonen M, Qualey R, et al. Salivary gland side effects commonly develop several weeks after initial radioactive iodine ablation. J Nucl Med. 2009;50:1605-10.

20. Jeong SY, Kim HW, Lee SW, Ahn BC, Lee J. Salivary gland function 5 years after radioactive iodine ablation in patients with differentiated thyroid cancer: direct comparison of pre- and postablation scintigraphies and their relation to xerostomia symptoms. Thyroid. 2013;23:609-16. doi: 10.1089/thy.2012.0106.

21. Nakamura H, Miyauchi A, Miyawaki N, Imagawa J. Analysis of 754 cases of antithyroid drug-induced agranulocytosis over 30 years in Japan. J Clin Endocrinol Metab. 2013;98:4776-83. doi: 10.1210/jc.2013-2569.

22. Smith MB, Xue H, Takahashi H, Cangir A, Andrassy RJ. Iodine 131 thyroid ablation in female children and adolescents: long-term risk of infertility and birth defects. Ann Surg Oncol. 1994;1:128-31.

23. La Vignera S, Vita R. Thyroid dysfunction and semen quality. Int J Immunopathol Pharmacol. 2018;32:2058738418775241. doi: $10.1177 / 2058738418775241$.

24. Ceccarelli C, Canale D, Vitti P. Radioactive iodine (131I) effects on male fertility. Curr Opin Urol. 2008;18:598-601. doi: 10.1097/ MOU.0b013e32831367b3. 